\title{
RÉSOLUTION NO. 1
}

L'Assemblée Générale de l'Union Astronomique Internationale décide d'adopter la modification suivante des Statuts: A la fin des articles $11(a)$ et $11(b)$, la phrase suivante est ajoutée: 'Des exceptions à cette règle ne peuvent être envisagées que sur décision du Comité Exécutif.'

\section{RÉSOLUTION NO. 2}

L'Assemblée Générale de l'Union Astronomique Internationale demande au Comité Exécutif d'examiner la possibilité de modifier les Statuts, de telle sorte que l'intervalle de trois ans entre deux Assemblées Générales puisse être étendu à quatre ans, si telle est, après examen, l'opinion du Comité Exécutif.

\section{RÉSOLUTION NO. 3}

L'Assemblée Générale de l'Union Astronomique Internationale reconnaît l'intérêt scientifique des réunions régionales et recommande à leurs organisateurs de prendre les mesures appropriées en ce qui concerne les dates de ces réunions et leur programme, de telle sorte qu'elles ne constituent pas pour les pays membres une charge financière trop lourde.

\section{RÉSOLUTION NO, 4}

L'Assemblée Générale de l'Union Astronomique Internationale, considérant

(a) qu'il existe des besoins de datation selon un système décimal dans des buts divers en liaison avec l'utilisation de signaux horaires et de codes horaires transmis radioélectriquement,

(b) qu'il est souhaitable de rapporter une telle datation à $0^{\mathrm{h}} \mathrm{TU}$ comme début de la journée plutôt qu'à $12^{\mathrm{h}} \mathrm{TU}$,

(c) qu'un comptage continu des jours, le système des jours de la période julienne, a été depuis longtemps établi pour la datation en astronomie, chronologie, et dans les sciences connexes,

(d) qu'il est nécessaire d'éviter la prolifération de systèmes différents de datation,

(e) qu'une simple conversion du système classique des jours juliens, ci-dessus mentionné, en un comptage décimal moderne, serait avantageux,

$(f)$ que le système de comptage actuel des jours juliens, qui se réfère à un midi moyen de Greenwich comme début du jour, doit être maintenu sans discontinuité, et

( $g$ ) qu'un système de 'jour julien modifié' satisfaisant aux exigences ci-dessus est déjà utilisé, recommande

que le terme de 'jour julien modifié' et le symbole MJD soient utilisés seulement pour la quantité JD moins 2400000.5, MJD étant égal à 0 à la date du 17 novembre $1858,0^{\text {h }} \mathrm{TU}$.

Note: Il est recommandé que cette Résolution soit communiquée à l'ISO et aux autres organismes intéressés.

\section{RÉSOLUTION NO. 5}

L'Assemblée Générale de l'Union Astronomique Internationale recommande, pour la détermination de $z$ dans le spectre des objets fortement déplacés vers le rouge, l'utilisation des longueurs d'onde des raies dans le vide, lorsque la différence en $\lambda_{0}$ est significative.

$$
\text { RÉSOLUTION NO. } 6
$$

L'Assemblée Générale de l'Union Astronomique Internationale, 


\section{RESOLUTION NO. 1}

The General Assembly of the International Astronomical Union resolves to adopt the following change of the Statutes: At the end of Articles 11 $(a)$ et $11(b)$, the following sentence is added: 'Exceptions from this rule cannot be considered unless decided by the Executive Committee.'

\section{RESOLUTION NO. 2}

The General Assembly of the International Astronomical Union requests the Executive Committee to examine the possibility of a change in the Statutes such as to allow the three years interval between two General Assemblies to be extended to a four-year interval, if such is, after study, the opinion of the Executive Committee.

\section{RESOLUTION NO. 3}

The General Assembly of the International Astronomical Union recognizes the scientific interest of regional meetings and recommends to their organizers to take the appropriate steps so that the dates of these meetings and their programme be such as not to constitute for the member countries an excessive innancial burden.

\section{RESOLUTION NO. 4}

The General Assembly of the International Astronomical Union, considering

(a) that there exist requirements for dating in a decimal sequence for various purposes in conjunction with the use of radio time signals and radio time codes,

(b) that it is desirable to refer such dating to $0^{\mathrm{h}} \mathrm{UT}$ as the beginning of a day instead of $12^{\mathrm{h}} \mathrm{UT}$,

(c) that a cecimal day count, the Julian Day count, has long been in established use for dating in astronomy, chronology, and related sciences,

(d) that it is necessary to avoid a proliferation of different dating systems,

(e) that a simple conversion from the above-mentioned conventional Julian Day count to a modern decimal day count will be advantageous,

$(f)$ that the existing established Julian Day count which refers to a Greenwich Mean Noon as the beginning of the day needs to be maintained without discontinuity and,

( $g$ ) that a 'Modified Julian Day' count satisfying the above requirements is already in use, recommends

that the term 'Modified Julian Date' and the symbol MJD be used only for the quantity JD minus 2400000.5 , MJD being equal to 0 on 1858 November $17,0^{\mathrm{h}} \mathrm{UT}$.

Note: It is recommended that this Resolution be communicated to ISO and other concerned bodies.

\section{RESOLUTION NO. 5}

The General Assembly of the International Astronomical Union recommends, for the determination of $z$ in the spectrum of objects of large redshifts, the use of vacuum wavelengths of lines, wherever the difference in $\lambda_{0}$ is significant.

\section{RESOLUTION NO. 6}

The General Assembly of the International Astronomical Unıon, 
reconnaissant

que la seconde du Système International peut être réalisée en pratique avec une précision meilleure que 2 sur $10^{13}$,

que les distances sur Terre et dans l'espace sont mesurées par le temps de parcours de rayonnement électromagnétique, et que le Système des Constantes Astronomiques de l'UAI sera révisé dans le cours des trois années à venir, considère

qu'une valeur unique de la vitesse de propagation du rayonnement électromagnétique devrait être utilisée lorsque l'on exprime en mètres les résultats des mesures de distance les plus précises, et

recommande

que, lorsque la valeur la plus précise de la vitesse de propagation du rayonnement électromagnétique dans le vide est nécessaire, la valeur proposée par le Comité Consultatif pour la Définition du Mètre à sa réunion de juin 1973, c'est-à-dire:

soit utilisée,

$$
c=299792458 \text { mètres par seconde, }
$$

que cette valeur de la vitesse de propagation du rayonnement électromagnétique soit incorporée dans la révision prochaine du Système des Constantes Astronomiques de l'UAI, et

que le Comité International des Poids et Mesures maintienne cette valeur dans toute éventuelle définition du Mètre.

\section{RÉSOLUTION NO. 7}

\section{Proposée par le Comité des Résolutions}

Sur les résolutions adoptées par les Commissions

Considérant qu'il lui est pratiquement impossible d'accorder une attention particulière à chaque résolution adoptée par chacune de ses diverses Commissions et ayant une confiance entière en ses Commissions, cette Assemblée Générale désire exprimer son approbation des Résolutions adoptées par ses différentes Commissions, recommande aux astronomes de les mettre en application dans la limite de leurs possibilités, et demande au Comité Exécutif de veiller, autant que possible, à la compatibilité de ces résolutions et à leur application. 